\title{
ALTERNATIVES FOR DEVELOPMENT OF ORGANIZATIONAL CULTURE IN PUBLIC ADMINISTRATION
}

\author{
Cosmin Octavian DOBRIN ${ }^{a^{*}}$, Cristina DIMA $^{b}$, Ruxandra DINULESCU $^{c}$ \\ ${ }^{a, b, c}$ Bucharest University of Economic Studies, Romania
}

\begin{abstract}
Organizational culture is the basis for the harmonious development of unwritten values and norms that guide a good unfolding of services in public administration institutions. The efficiency and effectiveness of public administrations is dependent on the culture agreed by public clerk. However, in the current context, the political problems that public authorities have are increasingly complex and for this reason there is a real need to develop the organizational culture in public institutions. Moreover, we have to consider the pandemic context caused by the infection with the SARS-CoV 2 virus, so the acute need to digitize to a greater extent the public services, implicitly to develop the organizational culture. This research aims to identify and analyze the organizational features and culture in the public service, the relationship between organizational culture and performance and last but not least to propose a set of principles that can significantly contribute to a reform of public administration.
\end{abstract}

KEYWORDS: organizational culture, organizational development, public administration.

\section{INTRODUCTION}

In the last decade has been more and more discussions about the public services offered to the citizens and implicitly the failures, but also the dysfunctions of the public administrations and not infrequently these have been attributed to the organizational culture. In the specific literature, various authors argue that important changes in public administration are adopted by political leaders as a kind of redistribution of power, but trying to maintain the situation, without new and real prospects for development. The main argument of this stagnation is that through knowledge the political will can be subrogated (Barzelay, 2019).

In terms of public services that have become increasingly digitized, now more than ever, it is desired to develop the organizational culture that integrates the values necessary to provide competitive, transparent and responsible services. This paper presents a study accomplished in public administrations from the perspective of the concept of organizational culture, defined as a set of values, norms and beliefs of all actors operating in this sector (Cameron and Quinn, 2011).

In this regard, there are countless characteristic values that can be improved in terms of organizational culture in public administrations.

The notion of values is the most important aspect that defines the organizational culture of public institutions in Romania. For public clerk, the core values, such as: impartiality, loyalty, fairness, responsibility and fairness, which have been implemented and which have become essential values in the way they work, are values identified in the literature since the years 1980 (O'riordan, 2015). Although these values have been strongly promoted among public clerk, conflicts of value have arisen in the last decade in the context of modernizing public services and, in particular, the

\footnotetext{
* Corresponding author. E-mail address: cosmin.dobrin@man.ase.ro
} 
introduction of reforms in the new public management designed to ensure greater efficiency and effectiveness in public services in OECD countries (MacCarthaigh, 2008).

However, the simplistic analysis of values in terms of public services is totally different from the private sector due to political constraints. Also, the operating environment is different and seems to have an impact on the organizational culture and provides an image of the need for cultural change that can be much more difficult in the public service than in the private one.

\section{THE SIGNIFICANCE OF ORGANIZATIONAL CULTURE, TYPES OF ORGANIZATIONAL CULTURE, ORGANIZATIONAL CULTURE OF PUBLIC SERVICE - LITERATURE REVIEW}

\subsection{The Significance of Organizational Culture}

One of the most relevant definitions of the concept of culture is the characteristic behaviors and beliefs of a group. The term organizational culture appeared in the 1980s and was used by researchers in the field to describe both the climate and the practices that public institutions develop around their employees, respectively public clerk and the adopted values of public administration (O 'riordan, 2015).

Although it is a complex and difficult concept to understand, but also to identify in public institutions, the idea that organizational culture is a key factor in achieving strategic goals and performance in organizations is unanimously accepted.

The main reason why it becomes difficult to identify an organizational culture is that it "includes a set of self-evident values, expectations, but also collective memories" (Cameron and Quinn, 2011). Research on organizational culture is approached from two perspectives. Firstly, the need to understand what it represents and secondly, the identification of the types of organizational culture and how they work.

In the early 1980s, organizational culture was associated with a business phenomenon, according to Baker (2002), and this was identified in a number of publications such as the books of Ouchi, Pascale, and Athos (Ouchi, 1981; Pascale \& Athos, 1981) which stated that success in the Japanese economy could be due to the Japanese organizational culture, but also to the Total Quality Management approach.

After all, the special interest given to organizational culture, since the emergence of this concept and until now, is due to the recognition of its role in ensuring the performance of an organization (O'Reilly et al., 2014).

As specific organizational goals are formulated on the long, organizations become more formal and institutionalized. Each organization, respectively public institution develops its own values, beliefs and practices based on which the organizations are differentiated but also the success of each one.

Ouchi (1981) finds that the interest in organizational culture has increased significantly when decision makers realized that this is the key to an effective system.

In the context of permanent changes, most organizations need to reorient their way of carrying out activities in order to achieve their purpose and objectives. The first stage of this process is the correct identification of the type of culture needed to achieve the specific purpose and objectives. According to (O'riordan, 2015), for the proper motivation of human resources, the most important factor with a decisive role is the organizational culture.

Schein (2004), one of the most important analysts of the concept of organizational culture existing at several levels in organizations, identifies three levels in the following, bring up that the organizational level refers to the visibility and understanding of the cultural phenomenon for an individual outside organization:

\section{Artifacts - factors that provide an image of organizational culture}

Cultural artifacts are identified in the form of physical workspaces and the way they are organized, the technology used, the dress code approached and both verbal and non-verbal language, 
documents of the organization, both internal and external, regulations or methodologies that reveal identity organization but also the way in which it is perceived by others and last but not least the patterns of organizational behavior observed in the protocol.

2. Adopted values - represented by the purpose, objectives and strategies of the organization.

These are usually formulated appropriately so that they become a practical guide for members of the organization in how they behave in different contexts. In fact, these values may theoretically guide the approach in different situations, but in practice people react differently and it cannot be stated with certainty that an individual will act according to these organizational values.

3. Basic hypotheses - represented by the essence of organizational culture.

These are, in fact, taken for granted by organizations. According to Schein, basic assumptions are the most important aspect of organizational culture. Changing an organizational culture is the biggest challenge, due to the fact that basic assumptions are perceived as rules that cannot be discussed or improved (Schein, 2004).

In the 1990s, Johnson and Scholes developed a cultural network that included six interdependent elements called the work environment model.

In fact, this model represents Schein's more complex version of artifacts, values, and working hypotheses.

The connections between the approaches are presented in Table 1.

Table 1. Perspectives of organizational culture

\begin{tabular}{l|ll}
\hline Cultural $\boldsymbol{w e b}$ & \multicolumn{1}{c}{ Schein } \\
\hline $\begin{array}{l}\text { Symbols and titles } \\
\text { Power relations }\end{array}$ & $\begin{array}{l}\text { The visual elements of the organization } \\
\text { The most influential decision makers }\end{array}$ & \multicolumn{1}{c}{ Artefacts } \\
Organisational structure & $\begin{array}{l}\text { Formal and informal aspects } \\
\text { The way in which the behavior influences the } \\
\text { performance of the administration } \\
\text { Behavior and daily actions of civil servants }\end{array}$ & \\
Rituals and routines & $\begin{array}{l}\text { Both the events and the people who gained the } \\
\text { status of folklore }\end{array}$ & Adopted values \\
Myths and stories & $\begin{array}{l}\text { The mission of the organization, its functions, } \\
\text { purpose and objectives. }\end{array}$ & Basic hypotheses \\
\hline
\end{tabular}

Source: adapted from O`riordan (2015), p.11

\subsection{Types of organizational culture}

From the research carried out in the specialized literature regarding the organizational culture, it can be stated that, on the one hand, it strengthens the commitment to the organization, and on the other hand, it significantly increases the uniformity in the employees' behavior.

If we look at it from the employees' perspective, the organizational culture is important because it diminishes the ambiguity, suggesting the way of carrying out the activities and processes, as well as their importance.

Thus, organizational culture becomes a cause of the "inertia of the organization", i.e. as it becomes stronger; it can prevent to a greater extent the reactions to change.

Therefore, due to the fact that there are different perspectives on the concept of organizational culture and what it represents, there are also different perspectives on how it works. 
Although organizational culture differs from organization to organization, commonalities have been identified, and researchers (Deal and Kennedy, 1982; Denison, 1990) have created models that provide information about organizational culture indicators. The overall picture of competing values is the notion of understanding the culture of an organization, which evolves from empirical research (Quinn and Rohrbaugh, 1983; and Zammuto and Krakower, 1991) on the effectiveness of organizations. Subsequently, the indicators were divided into two, an internal versus external dimension, respectively a control versus flexibility dimension. The two dimensions are the axes of the frame, which are divided into four types of culture (Table 2).

Table 2. The dimensions of organizational culture

\begin{tabular}{l|ll} 
& Stability/ Control & $\begin{array}{l}\text { Change/ } \\
\text { Flexibility }\end{array}$ \\
\hline $\begin{array}{l}\text { Internal focus / Integration } \\
\text { External focus / }\end{array}$ & Hierarchy & Clan \\
Differentiation & Market & Adhocracy
\end{tabular}

Source: adapted from O`riordan (2015), p.14

According to research in the specialized literature, it appears that organizations focused on the internal dimension focus mainly on aspects of integration and communication, and those focused on the external dimension encourage both development and interaction outside the organization. Regarding the second axis, organizations focus on cohesion and control versus adaptability and spontaneity.

According to researchers Cameron and Quinn (2011), the resulting four quadrants represent the four types of culture, as follows:

1. The culture of the clan (internal and flexible concentration) is represented by a pleasant/nice place of activities, in which the leaders act protectively;

2. The culture of adhocracy (external and flexible focus) is represented by a dynamic place of activities, in which leaders through their actions stimulate innovation;

3. Market culture (external and controlled focus) is represented by a place of competitive activities, where leaders are tough;

4. The culture of the hierarchy (internal and controlled concentration) is represented by a structured place of activities, in which the leaders are the coordinators of the activities.

\subsection{Organizational culture of public service}

Within the public institutions, the awareness of the cultural characteristics, implicitly of the created organizational culture is particularly important, both at the level of decision makers and at the level of public clerk, especially in the event of possible changes in the respective system.

On the other hand, public sector organizations differ from private ones, from the perspective of organizational culture which is highlighted by the influence of the political system rather than that of the market of which it is part.

\section{OLD PUBLIC ADMINISTRATION, NEW PUBLIC MANAGEMENT, AND THE NEW PUBLIC SERVICE}

\subsection{Old public administration}

The dominant approach of public administration in the twentieth century, largely influenced by the ideas of Max Weber, was based on a model of bureaucracy consisting of the principles of both 
hierarchy and meritocracy. The model was based on centralized control, rules and guidelines, divided implementation policies and used hierarchical organizational structure (Osborne, 2006). The model was designed to streamline financial and human resources (Robinson, 2015).

The researchers Minogue (2001) and McCourt (2013) identified the main features of this model: the separation of decision makers from the political and administrative system; the administration must be transparent and governed by concrete rules; administrators are appointed on the basis of professional qualifications and training; there must be a hierarchy in terms of human resources and implicitly the tasks of each employee; the resources belong to the institution and not to the public clerk.

Thus, the "command and control" approach of public administration was a point of reference for all bureaucratic systems introduced throughout the world under colonial rule. In the desire to make the public administration system more efficient, many countries have adopted this model, but it has worked as expected in only a few countries, while in others it has led to a decrease in the efficiency of the public system (Minogue, 2001; McCourt, 2013).

\subsection{New Public Management}

Osborne's approach to New Public Governance (NPG) is completely different from the previous model. This lead citizens and their needs in the lead role compared to the old public administration in which the reform was based on internal rules of administration (Osborne, 2006; Osborne, 2010). The author Bourgon (2007) also identifies the theory of the New Public Administration as one in which the public administration must be based on the common interest of the citizens, to the detriment of the individual interests of the political decision makers. The influence of citizens in the implementation of administrative policies and the provision of services fundamentally distinguishes the approach of the new public governance from the old one.

In the NPG, the government is treated as a decision-maker who collaborates with regional and local public administrations and acts together to deliberate policies and provide services and is no longer supposed to be the only force that establishes public policies and their implementation (Weber \& Khademian, 2008).

The author Osborne (2006) points out in the NPG approach that the emphasis is on interorganizational relations and the governance of all processes, in which trust and appropriate relations between administrations serve as basic governance mechanisms. In this sense, NPG is in contradiction with the previous approaches of the public administration, which were implemented paying special attention to the intra-organizational processes in the governmental field (Osborne et al., 2013).

\subsection{New Public Service}

The approach of the new public service (NPS) starts from the premise that the primary interest of the public management should be the citizens, respectively the civil community. Therefore, in this new conception, the main role of civil servants is to help the citizens to fulfill their common needs and interests, rather than to participate in the decisive actions of the administrations (Denhardt and Denhardt, 2000).

The model of the New Public Service approaches public management in a democratic style, based on the active involvement of citizens. Beyond the individual interest, the citizens act unitedly to solve the complex societal problems, supported by the public clerk whose role is to facilitate the opportunities for their involvement. Public managers need to acquire new skills for integration and involvement of citizens, which go beyond the old paradigm in which they only control and lead society under the guidance of policy makers, in order to solve complex problems of society.

In an attempt to identify solutions in the public interest and address the needs of members of society, governments will need to become accountable, accessible and responsive and work to serve the community. 
Similarly, researcher Bourgon (2007) uses a new concept, that of democratic citizenship, in which public administrators are not limited to meeting the demands of the community. Its approach to the new public administration includes four major elements, namely: building and consolidating collaborative relationships with community members; encouraging joint responsibilities of society; dissemination of public information in order to stimulate the common solution of public problems and identify all opportunities to involve citizens in administrative activities.

On the other hand, the new NPS model addresses the issue of public administrations and services in terms of digital transformations. It is well known that the efficiency of public services cannot be achieved without their digitization.

The application of new digital technologies would significantly contribute to streamlining the work method and implicitly to improving the relationship between the administration and civil society, due to the fact that citizens can follow in real time the public services offered, can access them and thus increase their involvement.

The potential offered by the new technologies through which practically the community has access to the information of the public administration was capitalized with the appearance of the new transparency agenda. IT\&C innovations aimed at increasing both transparency and accountability provide citizens with the opportunity to inform about the public policy-making process.

Finally, another important aspect of public management refers to the motivation of public clerk. Even if there have been major changes, whether there have been changes in internal or external working methodologies in terms of citizen involvement, it is imperative that attention be paid to the values and incentives that govern the behavior and performance of civil servants. The issue of motivation of civil servants/ public clerk is a complex one due to the need to understand how both rewards and sanctions can have a critical influence on motivation and implicitly on organizational performance (Table 3).

Table 3. The perspectives of the three approaches

\begin{tabular}{|c|c|c|c|}
\hline & Old public administration & New Public Management & New Public Service \\
\hline $\begin{array}{l}\text { Theoretical } \\
\text { foundations }\end{array}$ & $\begin{array}{l}\text { Theory of politics, native social } \\
\text { science }\end{array}$ & $\begin{array}{l}\text { Theory of economics, } \\
\text { positivist social science }\end{array}$ & Democratic theory \\
\hline $\begin{array}{l}\text { Rationality and } \\
\text { models of human } \\
\text { behavior }\end{array}$ & $\begin{array}{l}\text { Rationality from an } \\
\text { administrative point of view and } \\
\text { public interest }\end{array}$ & $\begin{array}{l}\text { Rationality from a technical } \\
\text { and economic point of view } \\
\text { and self-interest }\end{array}$ & $\begin{array}{l}\text { Strategic rationality } \\
\text { and interest for } \\
\text { citizens }\end{array}$ \\
\hline $\begin{array}{l}\text { Conception of the } \\
\text { public interest }\end{array}$ & Political and legal issuer & $\begin{array}{l}\text { Conciliation of individual } \\
\text { interests }\end{array}$ & $\begin{array}{l}\text { Exposing common } \\
\text { values }\end{array}$ \\
\hline $\begin{array}{l}\text { To whom are civil } \\
\text { servants } \\
\text { responsive? }\end{array}$ & Clients and stakeholders & Customers & Citizens \\
\hline $\begin{array}{l}\text { Role of } \\
\text { government }\end{array}$ & $\begin{array}{l}\text { Implementation is based on } \\
\text { policy objectives }\end{array}$ & $\begin{array}{l}\text { To establish and direct the } \\
\text { rules of the market }\end{array}$ & $\begin{array}{l}\text { Negotiating the } \\
\text { interests of citizens } \\
\text { and providing the } \\
\text { services they need }\end{array}$ \\
\hline $\begin{array}{l}\text { Mechanisms for } \\
\text { achieving policy } \\
\text { objectives }\end{array}$ & $\begin{array}{l}\text { Program administration through } \\
\text { public institutions }\end{array}$ & $\begin{array}{l}\text { Creating mechanisms and } \\
\text { incentives through both } \\
\text { private and non-profit } \\
\text { organizations }\end{array}$ & $\begin{array}{l}\text { Building coalitions } \\
\text { between public, } \\
\text { private and non-profit } \\
\text { institutions }\end{array}$ \\
\hline
\end{tabular}




\begin{tabular}{l|lll}
$\begin{array}{l}\text { Approach to } \\
\text { accountability }\end{array}$ & $\begin{array}{l}\text { Hierarchical - administrators } \\
\text { report to the leaders they have } \\
\text { elected }\end{array}$ & $\begin{array}{l}\text { The community according } \\
\text { to its own interests }\end{array}$ & $\begin{array}{l}\text { Multiple approach - } \\
\text { civil servants are } \\
\text { guided by laws, } \\
\text { professional values } \\
\text { and norms and by the } \\
\text { interests of citizens }\end{array}$ \\
$\begin{array}{l}\text { Administrative } \\
\text { discretion }\end{array}$ & $\begin{array}{l}\text { The discretion given to civil } \\
\text { servants is limited }\end{array}$ & $\begin{array}{l}\text { High latitude for fulfilling } \\
\text { entrepreneurial objectives }\end{array}$ & $\begin{array}{l}\text { Discretion is required, } \\
\text { but constrained and } \\
\text { responsible }\end{array}$ \\
$\begin{array}{l}\text { Assumed } \\
\text { organizational } \\
\text { structure }\end{array}$ & $\begin{array}{l}\text { Bureaucratic institutions with } \\
\text { top- down authority and control } \\
\text { of clients }\end{array}$ & $\begin{array}{l}\text { Decentralized public } \\
\text { institutions with primary } \\
\text { control within each of them }\end{array}$ & $\begin{array}{l}\text { Collaboration } \\
\text { structures with the } \\
\text { common management }\end{array}$ \\
$\begin{array}{l}\text { Assumed } \\
\text { motivational basis } \\
\text { of public servants }\end{array}$ & $\begin{array}{l}\text { Wages and benefits, public } \\
\text { service protection }\end{array}$ & $\begin{array}{l}\text { Entrepreneurship, desire to } \\
\text { reduce the size and } \\
\text { functions of government }\end{array}$ & $\begin{array}{l}\text { Desire to contribute to } \\
\text { the well-being of } \\
\text { society }\end{array}$ \\
\hline
\end{tabular}

Source: adapted from Robinson (2015), p. 10

\subsection{Changing the organizational culture}

The new vision in terms of public services cannot be implemented without a significant change in the way of working, and for this it is necessary to improve the field by:

1. A unified public system - management of public functions in a unified system;

2. Quality public services - Maximizing the degree of performance and potential of all civil servants;

3. Receptive public services - Implementing a new organizational culture, simplifying processes so that civil servants become more flexible and receptive; and

4. Transparent and accountable public institutions - Continuous improvement by accepting new procedures, ideas and challenges (Civil Service Renewal Plan, Department of Public Expenditure and Reforms, 2014).

In order to develop the organizational culture in terms of providing professional, transparent and competitive services, Katzenbach et al (2012) suggest the application of five principles that will support the change of the cultural system in order to increase the efficiency of public institutions, as follows:

1. Combining organizational strategy and culture: Often, in organizational practice, it is found that the strategy of an institution, of course imposed by the central government, becomes contradictory to the practices and behavior induced by the values of its culture. However, it turned out that the major importance was given to the organizational culture to the detriment of the imposed strategy. Many public system decision-makers have struggled with cultural intransigence, but without starting from the basic premise of what needs to be changed or improved in order for organizations to truly achieve their goals. The first stage in order to change the organizational culture is to identify the main cultural features that are in line with the strategy so that they are properly promoted in order to achieve the proposed goal, that of combining organizational culture with strategy.

2. Focus on fundamental changes in behavior: In general, any change is difficult, especially since it is a change in the values of the public system in terms of public clerk. Therefore, at this stage it is necessary to emphasize the essential behaviors of those officials who understand the importance of culture and its development.

3. Identifying the strengths of the existing organizational culture: looking at and analyzing organizations in their complexity, the tendency is to initially observe negative traits and behaviors, but given the rationale for this principle, attention should be paid to the strengths of culture and their evolution. Although impartiality and fairness have been the starting point in building the 
culture of public service, lately I have noticed that a sense of mistrust has been created regarding the performance of the organization and any approach that places the civil servant in the lead role, individually and its performance. Change cannot be a success that contributes to the efficiency of the system, if it is imposed, but rather it is necessary that the core values be recognized as part of a win-win approach for both decision makers and officials and implicitly for citizens.

4. Integration of formal and informal approaches: both categories support the promotion of essential behaviors and values in order to achieve strategic objectives and achieve the expected performance. Usually, institutions are more open to adopting formal methods through which changes in behavioral culture (rules, methodologies, etc.) occur, to the detriment of informal ones (emotional behavior).

5. Measurement, respectively monitoring of cultural evolution: this principle encourages permanent monitoring and implicitly the evaluation of the progress registered at cultural level. In order to achieve the improvement of the values, it is necessary to measure them so as to identify the tangible evidence that positively impacts the progress. The consequences that need to be given more attention in terms of progress are the performance of the institution, the fundamental behaviors, the specific stages of change and the basic cultural attitudes.

\section{CONCLUSIONS}

In view of the approaches to public administration and management analyzed in this paper, public sector reforms require attention and consistency from three perspectives.

First of all, various approaches are needed, and the context provides a first overview of what their application would entail: there is no predefined model of public management that contains a perfect solution to the deep problems of public administration. The gradual reconsolidation of the culture of public institutions represents the main challenge through a construction of the public system in an objective way, starting from an authority and basic administrative capacity.

Second, in order to empower service providers and increase internal competition, countries with a basic organizational structure for a proper public administration will be able to implement reforms for a new way of public administration.

Digital governance can enhance efficiency and transparency for the new public management, and an overall government-wide perspective can reduce the risks of inconsistency and fragmentation. Public sector reforms must be based on the interests and needs of citizens rather than on the technocratic impulse of civil servants or the personal interests of elected politicians, so a fundamental argument is based on the elements of what is defined as a new public service.

These steps in which the government is deficient, in order to be successful, should validate two sets of essential conditions. The vast majority of civil servants are elected on the basis of their political choices, without analyzing their skills and desire to work for the community and to meet the needs of their citizens. In order to place citizens at the top of the public service pyramid, it is necessary to fundamentally change the mentality of civil servants, where reforms are implemented to change behaviors and values as well as increase administrative capacity, focused on efforts to stimulate motivation.

Such approaches require an extremely different method to recruitment and professional development and the chances of success are much higher in political circles that adopt transparency and accountability and expose public servants to political oversight and receptivity to citizens.

Finally, an approach based on a set of public management traditions will be much more appropriate than a reform approach based on a structure that has performed politically and economically.

This approach provides the appropriate and necessary solutions for change and not a guide to good practice. The implementation of these new development directions would require a huge sustained effort so that the citizens become the center of interest of the reform of the organizational culture within the public administrations. 


\section{ACKNOWLEDGMENT}

This paper is a result of the research developed within the project "Managementul culturii organizaționale: comparație între sectorul public și cel privat"(Organizational culture management: comparison between public and private sectors) from Bucharest University of Economic Studies, Romania.

\section{REFERENCES}

Baker, K. A. (2002). Organizational Culture. Retrieved September 10, 2021 from http://www.au.af.mil/au/awc/awcgate/doe/benchmark/ch11.pdf

Barzelay, M. (2019). Public Management As a Design-Oriented Professional Discipline. UK: Edward Elgar Pub

Bourgon, J. (2007). Responsive, Responsible and Respected Government: Towards a New Public Administration Theory. International Review of Administrative Sciences, 73(1), 7-26

Cameron, K. S., \& Quinn, R. E. (2011). Diagnosing and Changing Organizational Culture: Based on the Competing Values Framework. John Wiley \& Sons

Deal, T., \& Kennedy, A. (1982). Corporate Cultures: the Rights and Rituals of Organisation Life. Addison Wesley

Denhardt, R. B., \& Denhardt, J. V (2000). The New Public Service: Serving Rather Than Steering. Public Administration Review, 60(6), 549-559

Denison, D. (1990). Corporate Culture and Organizational Effectiveness. New York: Wiley

Department of Public Expenditure and Reform (October 2014) The Civil Service Renewal Plan, Retrieved August 20, 2021, from http://www.per.gov. ie/en/civil-service-renewal/Plan

Katzenbach, J. Steffen, I., \& Kronley, C. (2012). Cultural Change that Sticks. Harvard Business Review

MacCarthaigh, M. (2008). Public Service Values, Committee for Public Management Research Discussion, Paper Number 39, Dublin: Institute of Public Administration. Retrieved September 12, 2021 from http://www.ipa.ie/pdf/cpmr/CPMR_DP_39_PublicServiceValues.pdf

McCourt, W. (2013). Models of Public Service Reform: A Problem-Solving Approach. Policy Research Working Paper, No. 6428. Washington D.C: The World Bank. Retrieved August 9, 2021 from http://www-wds.worldbank.org/external/default/WDSContentServer/WDSP/IB/ 2013/04/30/000158349_20130430082936/Rendered/PDF/wps6428.pdf

Minogue, M. (2001) The Internationalization of New Public Management. In The Internationalization of Public Management: Reinventing the Third World State, W McCourt and M. Minogue, eds. Cheltenham: Edwin Elgar, 1-19

Ouchi, W. G. (1981). Organizational paradigms: A commentary on Japanese management and theory Z organizations. Organ. Dyn. 9, 36-43

O'Reilly, C. A., Caldwell, D. F., Chatman, J. A., \& Doerr, B. (2014). The Promise and Problems of Organizational Culture. Group Organ. Manag, 39, 595-625

O`riordan, J. (2015). Organisational Culture and the Public Service, State of the Public Service Series, Research Paper No 16, IPA an foras riaracháin Institute of public Administration.

Osborne, S. P. (2006). The New Public Governance?. Public Management Review, 8(3), 377-388. Retrieved July 7, 2021, from spp.xmu.edu.cn/wp-content/uploads/.../the-New-PublicGovernance.pdf

Osborne, S. P. (2010). The New Public Governance. London: Routledge. 
Osborne, S. P., Radnor, Z., \& Nasi, G. (2013). A New Theory for Public Service Management? Towards a (Public) Service-Dominant Approach. The American Review of Public Administration, 43(2), 135-158

Pascale, R., \& Athos, A. (1981). The Art of Japanese Management. New York: Simon and Schuster

Quinn, R. \& Rohrbaugh, J. (1983). A Spatial Model of Effectiveness criteria: Towards a Competing Values Approach to Organizational Analysis. Management Science, 29, 363-377

Robinson, M. (2015). From Old Public Administration to the New Public Service, Implications for Public Sector Reform in Developing Countries. Global Centre for Public Service Excellence

Schein, E. H. (2004). Organizational culture and leadership, 3rd ed. United States of America: Jossey-Bass

Weber, M. (1979). Economy and society. University of California Press, Berkeley

Weber, E. P., \& Khademian, A. M. (2008). Wicked Problems, Knowledge Challenges, and Collaborative Capacity Builders in Network Settings. Public Administration Review, 68(2), 334-349

Zammuto, R., \& Krakower, J. (1991). Quantitative and Qualitative Studies in Organisation Culture, in Woodman Wand Passmore W (eds.), Research in Organizational Change and Development, Greenwich: JAI Press 